\title{
Sistema Nacional de Cultura: a tradução do dinâmico e do formal nos municípios da região Sul
}

\section{National Culture System: the translation of the dynamic and the formal in the municipalities of the South Region}

\author{
Cristina Amélia Carvalho ${ }^{1}$ \\ Rosimeri Carvalho da Silva² \\ Rodrigo Gameiro Guimarães ${ }^{3}$
}

\begin{abstract}
Resumo
A trajetória das políticas públicas da cultura no país, desde a era Vargas até o atual momento de institucionalização do Sistema Nacional de Cultura (SNC), evidencia a disputa entre os agentes sociais que lutam pela preservação da hegemonia de um modelo excludente e aqueles que defendem a cultura como um direito social. A construção e a instauração do Sistema pela sua própria lógica, só podem ser concretizadas a partir da mobilização nacional dos dirigentes estaduais e municipais da cultura e da sociedade civil organizada. O SNC envolve sistemas organizativos e institucionalizados nos três níveis federativos, numa articulação institucional regulada por normativas, instrumentos, aparatos e negociações. Nossa reflexão sobre a construção do SNC considera as informações sobre a dinâmica, o aparato cultural e a institucionalidade da cultura nos municípios brasileiros, recolhidas pelo IBGE. Interpretamos e discutimos os dados da região Sul, a fim de identificar as potencialidades dos municípios e as necessidades que se apresentam para a efetivação de um sistema complexo de gestão e política públicas. Essa discussão nos permite algumas projeções acerca da envergadura da tarefa que deverá mobilizar a imensa maioria dos municípios do país na desconstrução de tradições arraigadas no exercício do governo. Nesse sentido, é a partir da pedagogia do oprimido e da educação como prática da liberdade de Paulo Freire que o planejamento situacional de Matus poderá intervir, tanto como abordagem crítica à realidade social, quanto apropriação do planejamento como ferramenta política de luta no campo social da política da cultura. Consideramos que esta seja uma oportunidade para experimentar um diálogo criativo, que coproduza conhecimento a partir de uma posição contra-hegemônica e para escapar da naturalização dos conceitos tradicionais da área da gestão, inadequados a uma realidade dinâmica, que não precisa repetir os modelos dominantes de empresa e de management.
\end{abstract}

Palavras-chave: Sistema Nacional de Cultura; política cultural; gestão da cultura; gestão municipal; região Sul; planejamento.

\section{Abstract}

The trajectory of public policy culture in the country since the Vargas era to the present time to institutionalization of the National Culture System (CNS), highlights the struggle that confronts the social agents who struggle to preserve the hegemony of an exclusionary model and those who defend the culture as a social right. The construction and implementation of the system by its own logic, can only come from the national mobilization of state and local leaders of culture and civil society. The CNS involves organizational and institutionalized systems in 3 federal levels, a joint institution governed by regulations, instruments, apparatus and negotiations. Our reflection on the construction of the CNS considers the information on the dynamics, the cultural apparatus, and the institutional culture in the municipalities, collected by the IBGE. We interpret and discuss data from the South Region to identify the potential of cities and the needs that come to the realization of a complex system of management and public policy. This discussion allows us to some projections about the size of the task to mobilize the vast majority of municipalities in the country in

\footnotetext{
1 Professora Adjunta da Escola de Administração da Universidade Federal do Rio Grande do Sul (UFRGS), pesquisadora do Observatório da Realidade Organizacional - RS, pesquisadora do CNPq. Endereço: Escola de Administração/UFRGS - Rua Washington Luiz, 855 - Centro - Porto Alegre/Rio Grande do Sul - Brasil - Cep: 90010-460. E-mail: cris_carvalho@uol.com.br

2 Professora Associada da Escola de Administração da Universidade Federal do Rio Grande do Sul (UFRGS), coordenadora do Observatório da Realidade Organizacional - RS, pesquisadora do CNPq. Endereço: Escola de Administração/UFRGS - Rua Washington Luiz, 855 - Centro - Porto Alegre/Rio Grande do Sul - Brasil - Cep: 90010-460. E-mail: rfcsilva@ea.ufrgs.br

3 Professor Assistente da Universidade Federal de Alagoas, pesquisador do Observatório da Realidade Organizacional - PE. Endereço: Campus A.C. Simões Av. Lourival de Melo Mota, Bloco 16, $1^{\circ}$ andar - Tabuleiro do Martins - Maceió/Alagoas - Brasil - Cep: 57072-970. E-mail: rgameirog@yahoo.com.br
}

Artigo submetido em julho e aceito em outubro de 2009 
the deconstruction of traditions rooted in governance. In this sense, is from the pedagogy of the oppressed and education as a practice of freedom of Paulo Freire, that planning situational Matus could act as a critical approach to social reality, and appropriation of planning as a tool of political struggle in the social policy culture. We believe that this is an opportunity to experience the creative dialogue that co-produce knowledge from a counter-hegemonic position and to escape the naturalization of concepts from the area of management, are not suitable to a dynamic reality that does not need to repeat the dominant models business and management.

Key words: National Culture System; cultural policy; cultural management; management of municipalities; South Region; planning.

\section{Introdução}

A descrição da complexa trama organizacional, processual e institucional do Sistema Nacional de Cultura ( $\mathrm{SCN}$ ) e o uso da ideia de sistema não podem nos conduzir à leitura de um cenário de cunho eminentemente técnico e normativo. A concepção sistêmica é, de fato, de grande utilidade para delinear, ordenar e compor um arranjo organizativo complexo como uma política pública de alta complexidade e abrangência. Entretanto, sua lógica imanente, enraizada na biologia, privilegia a abordagem harmoniosa do todo e da relação entre as partes, a construção positiva em direção a um objetivo comum.

A trajetória das políticas públicas de cultura no país, da era Vargas até o atual momento de institucionalização do SNC, é descrita adiante de forma sucinta e mostra uma acirrada disputa entre os agentes sociais. De um lado está a luta para preservar a hegemonia de um modelo excludente, elitista e centralizador de política, que confere vantagens e nenhuma concorrência aos atores tradicionais. De outro lado, numa ação contra-hegemônica, defende-se não apenas a cultura como um direito social, mas também a construção do SNC como atual etapa da luta social.

O SNC é fruto da luta social travada por um sem número de agentes sociais, artistas, produtores culturais, intelectuais e militantes políticos que, levando em conta suas representações de mundo, bem como a pluralidade tanto de espaços territoriais quanto de formas de expressão e de representação da cultura, lutam pelo fortalecimento da cidadania, pela transformação social e pela emancipação dos sujeitos.

Vivemos um momento privilegiado de inflexão da democracia, no que diz respeito à formulação das políticas públicas da cultura. Além disso, estamos diante da complexidade inerente ao desenho e à institucionalização de um sistema nacional que articula os entes federativos e a sociedade civil no universo plural, polissêmico e disseminado da cultura. Esses fatores seriam razão suficientemente forte para o perigoso encantamento que exerce, tanto o domínio das técnicas - de gestão, de planejamento e de engenharia institucional - que a hercúlea tarefa demanda, quanto a pretensa neutralidade que adere, por inércia ou alienação, a essas habilidades.

Defendemos que o atual processo de construção do SNC é fruto da luta social de amplos e dispersos setores da sociedade, não constituindo seu fim, mas, pelo contrário, uma etapa na qual cabe recrudescer a disputa pela ideias que valorizem os aspectos políticos e sociais do processo.

Argumentamos que um dos caminhos é a efetiva descentralização da política de cultura e a adesão ao SNC nos municípios brasileiros. Exemplificamos nossa discussão a partir de um retrato da região Sul do país. Defendemos que a participação ampliada e qualificada, bem como a intervenção crítica, tanto no âmbito do governo municipal quanto no da sociedade civil no espaço local, implica travar um embate no plano ideológico. Trata-se de um embate sobre o caráter que se irá imprimir à política de educação e formação em gestão cultural e dos pressupostos e métodos que orientarão o sistema informacional sobre a cultura.

Reconhecemos e defendemos ainda que sistemas de grande complexidade, como é o caso do SNC, exijam métodos cientifica e tecnicamente fundamentados. Contudo, ousamos inferir que este não é o momento de se privilegiar a eficiência como valor preferencial, mas, sim, o exercício da política como método referencial, a partir de uma participação ampla, qualificada e crítica. Essa participação deve ocorre, em particular, nos 
espaços locais, seja no âmbito do Estado quanto no da sociedade civil, de onde o Sistema descentralizado poderá florescer como conquista histórica e reduzir a exclusão político-social.

Nossa reflexão sobre a problemática delineada busca seus fundamentos em autores que desenvolveram sua obra em torno do pensamento crítico sobre a América Latina, bem como as informações sobre a situação da infraestrutura para a cultura nos municípios da região Sul do país, apresentadas pelo Instituto Brasileiro de Geografia e Estatística (IBGE). Discutiremos essas informações à luz das diretrizes para a construção do SNC, visando identificar as potencialidades dos municípios e as necessidades que se apresentam para a efetivação de um sistema complexo de gestão e política públicas.

\section{De Matus a Freire: a educação no planejamento para a compreensão crítica da realidade}

A principal crítica de Matus (1996a) ao pensamento estratégico tradicional é pelo seu caráter assistemático nas mais variadas áreas. Essa crítica não exclui, pelo contrário, a gestão pública, particularmente, no âmbito municipal. O improviso, o amadorismo e a falta de planejamento são responsáveis, segundo Matus (1996b), pelas dificuldades de formular, implementar e articular as políticas. As rotinas da administração emergencial do quotidiano, sem um caráter sistemático e tomando a ação de governar como uma arte, respondem pela incapacidade de traçar planos e focar as ações de governo em objetivos predeterminados.

Para o autor (MATUS, 1996b), que teve participação significativa nas discussões sobre métodos de planejamento na construção do Sistema Único de Saúde (SUS), o modo tradicional (ou normativo) de pensar o planejamento da ação de governo contém pressupostos que impedem uma intervenção transformadora da realidade pelos atores sociais. Ao se reduzir à dimensão econômica, separa o aparato técnico-normativo da política e, dessa forma, reforça a separação entre a teoria e a prática, o pensamento e a ação.

Esse modelo centraliza a ação de planejar no governo, visto como único sujeito ativo, que, distanciado do objeto a ser planejado - os outros atores sociais e as interações -, prediz comportamentos, diagnóstico único de cenários e contextos estáveis e imutáveis. A tendência é a de consecução de um objetivo determinado por ele $a$ priori (MATUS, 1996b).

Por que planejar nesses moldes tão visivelmente determinísticos ainda tem tantos adeptos nas faculdades de administração e nas consultorias espalhadas pelo Brasil? A resposta pode estar na segurança gerada pelo domínio da técnica, na racionalidade formal no campo científico e na legitimidade conferida por uma pretensa neutralidade mas, também, na inércia induzida pela aceitação geral de conceitos consolidados pela repetição. A este respeito Mészáros (2004) afirma:

Não foi em consequência de sua própria "lógica imanente" que a ciência moderna chegou ao tipo de orientação e aos resultados de pesquisas com os quais muitos cientistas hoje em dia estão profundamente preocupados, mas por causa da impossibilidade de separar seu desenvolvimento das exigências objetivas do processo de produção capitalista. Ela jamais pôde sonhar em estabelecer seus próprios objetivos de produção em um vácuo, seguindo apenas as determinações "imanentes" de uma situação de pesquisa "ideal". Ao contrário, ao longo de todo seu desenvolvimento, a ciência moderna foi obrigada a servir com todos os meios a sua disposição à expansão do valor de troca, dentro do quadro de um sistema de produção orientado para o mercado [...].

Na proposta de Matus (1996a, 1996b), planejar a gestão e a formulação de políticas públicas é um processo contínuo de articulação dinâmica de ideias, ações e indivíduos. Não pode, por isso, ser restrito a planos como peças documentais formalísticas que não retratem a dinâmica e a complexidade social, e nem permitirão intervir nos problemas efetivamente presentes na sociedade. Atingir o futuro desejado, no qual o outro seja considerado sujeito ativo, autônomo e com poder de também pensar o futuro à luz de sua visão de mundo, só pode acontecer por meio de planejamento no qual os diferentes interesses se expressem - em diferentes 
prioridades na ação, por exemplo -, os conflitos sejam postos no palco da negociação e o Estado seja considerado mais um dos atores sociais nesse palco.

Quando dizemos que planejar é tentar submeter o curso dos acontecimentos à vontade humana, não deixar 'que nos levem' e tratarmos de ser condutores de nosso próprio futuro, estamos nos referindo a um processo social, no qual o homem indivíduo realiza um ato de reflexão superior e reconhece que só a consciência e a força do homem coletivo pode encarnar tal vontade humana e enfrentar a correnteza dos fatos... (MATUS, 1997, p.13)

A construção de um sistema nacional como o SNC, que pressupõe ampla participação social e política dos três níveis federativos e da sociedade civil em todos os territórios, é um natural espaço social de exercício de um método que não engesse a dinâmica do processo de construção plural e inclua todos, de modo qualificado e crítico.

No entanto, a construção do SNC e dos sistemas que o formam, como os sistemas municipais de Cultura, será um desafio também no plano da educação de todos quanto ao modo de participação. Aos especialistas, deverá oferecer a aprendizagem do ouvir e aos segmentos historicamente excluídos, a aprendizagem do expressar. Assim, à proposta de Matus, soma-se, numa leitura educativa, a pedagogia de Freire (1987, p.42), que propõe a "denúncia de uma realidade desumanizante e anúncio de uma realidade em que os homens possam ser mais" como compromisso histórico e possibilidade de emancipação do homem. Escreve ainda o grande educador: "me parece que o primeiro aspecto a sublinhar é que a prática educativa é uma dimensão necessária da prática social, como a prática produtiva, a religiosa, a cultural, etc.” (FREIRE, 2001, p.34).

Nesse sentido, é a partir da pedagogia do oprimido e da educação como prática da liberdade de Freire que o planejamento situacional de Matus poderá intervir como abordagem crítica à realidade social, além de apropriação do planejamento como ferramenta política de luta no campo social da política da cultura (no caso da construção do SNC).

\section{A construção do SNC como campo de disputa}

Neste texto, Bourdieu (1996) auxilia a compreender a dinâmica estabelecida na construção das políticas públicas, a partir da ação dos agentes sociais participantes do processo no qual a política figura como o plano da disputa que se configura como o campo de luta de todos os envolvidos.

Nas sociedades, como espaços sociais ou estruturas de diferenças, há que se identificar o princípio gerador que estrutura a distribuição e a força dos tipos de capital que as compõem. Ao compreender assim um determinado espaço social, poderemos construir empiricamente um campo e a dinâmica de seus agentes na conservação e na transformação da estrutura de distribuição das suas propriedades ativas (BOURDIEU, 1996). Para Misoczky (2002, p.26), um campo é "um espaço de posições, entre atores sociais, em uma relação de mútua exclusão". Portanto, para identificar um campo social específico, há de se observar o que nele está em jogo, o que os agentes disputam, as estratégias que adotam e os capitais que valorizam.

A partir desses elementos, os agentes sociais tentam determinar as regras de funcionamento que melhor lhes convêm para a conquista de posição de poder no campo. Esses elementos estão em permanente mudança, conduzidos pelas estratégias adotadas em cada momento pelos agentes sociais envolvidos na disputa. A posição conquistada por um agente em um determinado momento será sempre disputada por outro. Quanto ao capital valorizado em cada momento - e que fortaleceu um dos agentes em disputa -, será sempre substituído em sua predominância simbólica por outro(s) agente(s) que detenha(m) outro tipo de capital e que conquistará(ão) predominância e posições de força se transformar(em) esse capital em capital simbólico. Assim, um campo social, que só existe porque algo é disputado por agentes efetivamente atuantes, é um espaço em constante construção. A conquista de uma posição se transforma imediatamente em alvo de disputa. Um capital que adquiriu valor na disputa que está sendo travada será o foco da disputa seguinte. Segundo Carvalho (2003, 
p.15-16), "[...] assim como num jogo de xadrez, as posições e os recursos de poder de cada um não têm valor por si próprios, mas em função das posições relativas de todos os atores no campo". Portanto, a dinâmica da construção do campo é permanente, assumindo por isso caráter primordial na análise.

As posições dos agentes num campo podem ser determinadas conforme o peso relativo dos diferentes tipos de capital e a quantidade global de seu capital (BOURDIEU, 1996). Thiry-Cherques (2006, p.38-40) descreve-os assim:

[...] Além do econômico, que compreende a riqueza material, o dinheiro, as ações etc. (bens, patrimônios, trabalho), Bourdieu considera: o capital cultural, que compreende o conhecimento, as habilidades, as informações etc., correspondente ao conjunto de qualificações intelectuais produzidas e transmitidas pela família, e pelas instituições escolares, sob três formas: o estado incorporado, como disposição durável do corpo (por exemplo, a forma de se apresentar em público); o estado objetivo, como a posse de bens culturais (por exemplo, a posse de obras de arte); estado institucionalizado, sancionado pelas instituições, como os títulos acadêmicos; o capital social, correspondente ao conjunto de acessos sociais, que compreende o relacionamento e a rede de contatos; o capital simbólico, correspondente ao conjunto de rituais de reconhecimento social, e que compreende o prestígio, a honra etc. O capital simbólico é uma síntese dos demais (cultural, econômico e social) (grifos nossos).

O capital simbólico, extraído do capital mais valorizado no campo - valor que está em constante disputa permite que os agentes que o detêm determinem regras e decisões e que estas sejam obedecidas. Não obstante, Bourdieu (1996, p.170) lembra que

[...] é preciso que um trabalho anterior, frequentemente invisivel e, em todo caso, esquecido, recalcado, tenha produzido, naqueles submetidos ao ato de imposição, de injunção, as disposições necessárias para que eles tenham a sensação de ter de obedecer sem sequer se colocar a questão da obediência.

Neste texto, procuramos entender a construção de políticas públicas culturais como um campo social no qual se disputa não apenas a definição das políticas, mas também a forma como estas são construídas e as ações decorrentes. Entendemos que a participação social é um elemento em jogo nesse campo e que sua definição e prática também são disputadas pelos agentes.

Bourdieu (1996) considera que o Estado é tanto instrumento de agentes como um campo de lutas (campo burocrático), ainda que diferente dos outros. Ele resulta de um processo de concentração dos diferentes tipos de capital (força física, coerção, econômico, cultural e capital simbólico), detendo uma espécie de metacapital que permite manipular a taxa de câmbio entre os capitais e lhe dá poder sobre os outros campos.

a gênese do Estado é inseparável de um processo de unificação dos diferentes campos sociais, econômicos, cultural (ou escolar), políticos, etc., que acompanha a constituição progressiva do monopólio estatal da violência física e simbólica legítima. Dado que concentra um conjunto de recursos materiais e simbólicos, o Estado tem a capacidade de regular o funcionamento dos diferentes campos [...]. (Ibidem, p.51)

Além disso, "[...] o Estado [...] é o lugar por excelência da concentração e do exercício do poder simbólico" (Ibidem, p.107). Esse poder exerce-se pela língua e relações de comunicação, por isso define o poder simbólico ou poder da linguagem como

[...] o poder de constituir o dado pela enunciação, de fazer ver e fazer crer, de confirmar ou de transformar a visão de mundo e, deste modo, a acção sobre o mundo, portanto o mundo; poder quase mágico que permite obter o equivalente daquilo que é obtido pela força (física ou econômica), graças ao efeito de mobilização, só se exerce se for reconhecido, quer dizer, ignorado como arbitrário. (BOURDIEU, 2005, p.14-15) 


\section{A descolonização do olhar}

O desafio de recuperar e "reler" os intelectuais, artistas e homens e mulheres brasileiros da cultura, que pensaram o Brasil a partir de suas próprias referências, é, ao mesmo tempo, um trabalho árduo ${ }^{4}$ e uma sucessão de descobertas do quanto se perde pela inércia da repetição da formação institucionalizada.

Assim, recupera-se a leitura esquecida de autores brasileiros como Guerreiro Ramos (1965), que propôs a redução sociológica como forma de domínio autônomo do conhecimento apropriado às necessidades do local. O autor defendia uma "descolonização das ideias", de forma que o estudioso realizasse a transposição de conhecimentos e experiências de uma perspectiva estrangeira para outra apropriada à realidade nacional. Ele advogava a existência de uma perspectiva brasileira que pode "olhar" os efetivos problemas nacionais e aguçar a capacidade de compreender a realidade, desafiando o pesquisador a não se descolar da consciência desse olhar. Guerreiro Ramos (1965, p.45) explicou a redução sociológica nestes termos:

Uma atitude metódica que tem por fim descobrir os pressupostos referenciais, de natureza histórica, dos objetos e fatos da realidade social. A redução sociológica, porém, é ditada não somente pelo imperativo de conhecer, mas também pela necessidade de uma comunidade que, na realização de seu projeto de existência histórica, tem de servir-se da experiência de outras comunidades.

Para Guerreiro Ramos (1965), a redução a ser empreendida na leitura da realidade social do Brasil exige, entre outros aspectos, uma atitude metódica que identifique e se centre no que é essencial na análise. Sua perspectiva é a de que todo objeto na realidade social é carregado de historicidade e de pressupostos; uma noção de mundo que considera a "reciprocidade de perspectivas", bem como uma recusa ao isolacionismo, que não deve ser confundida com um procedimento "crítico-assimilativo da experiência estrangeira", este sim defendido.

Mas de que adianta a preocupação com a importação acrítica da leitura e interpretação da realidade social brasileira - preocupação cuja importância se consolida quando aceitamos que a interpretação analítica dá suporte à prática - se não nos preocuparmos também com os "silêncios" no seio dessa própria realidade? Referimo-nos por silêncios à desvalorização histórica e socialmente imposta ao conhecimento popular, ao senso comum, ao que não é formalmente reconhecido nem cientificamente produzido e tecnicamente eficiente. Diz Holanda (2009, p.8) a esse respeito que:

As práticas organizativas populares são estigmatizadas por termos e expressões pejorativos, consideradas amadoras, caseiras, arcaicas, anacrônicas, sem sistematização do trabalho, tendo no improviso a regra, feita na correria (BRANT, 2004), feita naturalmente, na marra, apagando incêndios, de última hora, o que denota sua baixa credibilidade (VILAS-BOAS, 2005).

Santos (1989), ao refletir criticamente sobre a modernidade ocidental, apresenta uma nova possibilidade de pensar a realidade social, tendo como eixo as dimensões política e ética do conhecimento produzido, a negação das pretensões universalizantes da ciência moderna, bem como de sua legitimidade bebida na pretensa neutralidade axiológica. Defende ainda o caráter situacional do conhecimento derivado do contexto social, político e institucional em que é produzido, além da valorização de outros saberes que foram marginalizados pela monocultura do saber científico, sobretudo, o senso comum (HOLANDA, 2009).

A construção do SNC, no cenário polissêmico da cultura brasileira, pode se tornar uma experiência ímpar para explorar outras possibilidades nos modos de gestão e de formação das políticas no campo da cultura, a partir da conquista da consciência da possibilidade de se construir outras formas de conhecer.

4 Esta é a proposta do projeto Contribuições do Pensamento Social Brasileiro para a Qualificação do Ensino e da Pesquisa em Administração Pública, aprovado no âmbito do Edital Pró-Administração-Capes no 09/2008, que envolve a Escola Brasileira de Administração Pública e de Empresas (Ebape)/FGV, a Universidade Federal do Rio Grande do Sul e a Universidade Federal Fluminense nos próximos quatro anos, sob a coordenação do prof. Paulo Emílio Martins. 
Consideramos que seja uma oportunidade para escapar da naturalização dos conceitos tradicionais de amplo uso e divulgação, como os da área de gestão - repetidos acritica e exaustivamente, sem adequação a uma realidade dinâmica que não precisa repetir os modelos dominantes de empresa e management, entre outros -, e de experimentar um diálogo criativo que coproduza conhecimento a partir de uma posição contra-hegemônica.

\section{De Vargas à democracia}

O Estado Novo, que se inicia em 1937 com o golpe de estado comandado por Getúlio Vargas, tem a marca do autoritarismo e do populismo, além de um projeto político com origens no repúdio ao comunismo, mas também ao liberalismo representado pela Constituição de 1934. Na "era Vargas" toma impulso o processo de modernização da sociedade brasileira e a construção de um aparato estatal capaz de intervir na economia, de criar empresas públicas para desenvolver a infraestrutura socioeconômica do país e de regular a ampliação dos direitos civis.

O regime do Estado Novo fecha o Congresso Nacional, proíbe os partidos políticos, submete os estados da Federação ao poder central e, em nome da eficiência e da racionalidade administrativa, o aparato estatal é modernizado. ${ }^{5}$ É um período durante o qual se equilibram a continuidade da lógica excludente dos estamentos populares, a preservação dos privilégios da elite que ocupa as instâncias de poder e decisão - tanto no âmbito público como no privado - e uma edificação institucional que, de um lado, coopta parcela dos "formadores de opinião" e, de outro, reforça o modelo perverso existente, embora sob o manto da modernização e do desenvolvimento do país.

Criado em 1930, o Ministério dos Negócios da Educação e Saúde Pública é, segundo Moisés (1998), a primeira estrutura institucional que tem o papel de promover políticas públicas para a cultura. Estas dão eco à lógica preservacionista dominante, que foca a proteção do patrimônio e o apelo simbólico da identidade nacional ajustada ao gosto do Estado centralizador (CURY, 2002).

Durante o Estado Novo, no âmbito da cultura, assiste-se a um investimento significativo no plano simbólico/ideológico, com o objetivo de legitimar o projeto nacional do regime. A cultura torna-se um campo político importante na construção da estratégia de Estado, e a formulação das políticas públicas para a área é direcionada à preservação do patrimônio histórico.

Os bens culturais classificados como patrimônio deveriam fazer a mediação entre os heróis nacionais, os personagens históricos, os brasileiros de ontem e os de hoje. Essa apropriação do passado era concebida como um instrumento para educar a população a respeito da unidade e permanência da nação. (A ERA VARGAS..., 1997)

A centralização da concepção e promoção das políticas, nomeadamente das políticas para a cultura, no governo federal (ao qual cabia definir os valores culturais a serem preservados pela sociedade) e a submissão de estados e municípios são marcas importantes do período. Não obstante, algumas instituições culturais conquistaram autonomia, embora muito mais pelo seu isolamento técnico e por não oferecer ameaças ao regime (CURY, 2002).

No confuso cenário político e ideológico do período entre guerras, a criação desses órgãos e a adoção de políticas específicas para a área cultural deixou um legado que, se tem forte sentido estatista em muitos aspectos, deixou-se permear, no entanto, pela participação de setores da intelectualidade

\footnotetext{
${ }^{5}$ É criado o Departamento Administrativo do Serviço Público (Dasp) e o Instituto Brasileiro de Geografia e Estatística (IBGE). Entre 1937 e 1945, são criados o Serviço do Patrimônio Histórico e Artístico Nacional (Sphan), o Instituto Nacional do Livro (INL), o Serviço Nacional do Teatro (SNT), o Instituto Nacional da Música (INM) e o Instituto Nacional de Cinema Educativo (INCE). Também datam desse período as iniciativas de criação ou de consolidação dos principais museus públicos do Brasil (MOISÉS, 1998).
} 
brasileira, estabelecendo, aliás, uma característica que marcaria, por muito tempo, a administração pública da cultura brasileira: por influência desses setores, algumas das mais importantes políticas culturais surgiram na vigência de regimes não-democráticos. Por isso, a tradição de gestão cultural esteve, muitas vezes, mais sob a influência da burocracia do Estado que de setores da sociedade civil, mesmo em momentos de mudanças institucionais importantes. (MOISÉS, 1998, p.25-26)

A vitória da democracia ao final da II Guerra Mundial acelerou o declínio do Estado Novo, e os espaços criados e administrados por uma estrita visão técnica foram pressionados a politizar sua ação. Entretanto, a alternância de poder ocorreu pelas mãos de setores conservadores, que implantaram uma política econômica liberal de nefastas consequências para a imensa maioria da população, enquanto no plano político registrou-se a forte influência estadunidense sobre o país. O nacional-desenvolvimentismo do governo Juscelino Kubitschek inaugurou um forte crescimento de marcado cunho econômico, no qual as políticas para a cultura não tiveram lugar.

O período da ditadura militar, entre 1964 e meados da década de 1980, trouxe elementos diferenciais para as políticas públicas culturais. Foi reforçado o desenho tecnoburocrático e o esvaziamento da política, por meio do corte autoritário do regime, da violenta repressão que este imprimia e do consequente fechamento dos poucos espaços políticos, ainda que precários (sindicatos e partidos), de negociação de interesses, criados no período populista.

Conforme ocorrera no Estado Novo, a cultura, como esfera de legitimação do projeto político, ressurgiu nas tentativas de se obter a adesão de artistas e intelectuais para as políticas dos governos militares. Do mesmo modo, neste período, o fortalecimento do aparato institucional ${ }^{6}$ sofre nova arrancada, que reforçou a centralização das decisões e da concepção das políticas. A resistência à repressão por meio das expressões culturais deu origem, por exemplo, aos Centros Populares de Cultura (CPCs), formando um amplo movimento de contracultura que se espraiou pelos estados e municípios do país.

Em 1975, é instituída a Política Nacional de Cultura (PNC), um marco na história das políticas culturais do país por ser a primeira política nacional da área e resultado do Plano de Ação Cultural (PAC). Esse documento preserva a continuidade da lógica centralizadora, tecnocrática e tutelar em relação aos espaços locais, opondose à capilaridade da enorme diversidade cultural que luta por sua preservação no tecido social do país.

A tecnoburocracia, centralizadora e localizada no governo federal, faz do planejamento uma peça altamente formalizada. Neste modelo de planejamento, orientado por uma falsa mentalidade técnica amparada na racionalidade burocrática, a tecnoburocracia se erige como único sujeito pensante e estrategista. Para ela, o contexto é povoado de sujeitos que se comportarão reativamente, e positivamente aos seus sofisticados procedimentos formais de predição do futuro, como criticou Matus (1996a).

Os anos 1980 são marcados pelo processo de redemocratização e a decorrente ampliação da dinâmica da sociedade civil. Para Moisés (1998), o fim do período militar suscitou várias tentativas de reconstrução da administração pública federal, inclusive, com a criação de novos ministérios, entre eles, o da Cultura, comandado por Celso Furtado. Em 1986, foi promulgada a primeira lei federal de incentivo fiscal à cultura, marco na relação do Estado com a comunidade artística, conhecida como Lei Sarney. A nova lei, que buscava atrair investimentos privados mediante isenção fiscal, abriu para o mercado as decisões sobre cultura. Foi uma resposta à crescente pressão da sociedade por um maior suporte estatal ao setor que, no entanto, resultou no fortalecimento da concepção liberal de gestão da cultura, ao deixar a condução das ações por conta do mercado.

\footnotetext{
${ }^{6}$ Em 1969, é criada a Empresa Brasileira de Filmes (Embrafilme), que viria a ter um papel importante no estímulo à produção cinematográfica. Em 1972, os assuntos culturais e artísticos são centralizados no Departamento de Assuntos Culturais (DAC) do MEC, que em 1975 se transforma na Fundação Nacional de Artes (Funarte). Em 1973, são criados o Conselho Nacional de Direito Autoral e o Centro Nacional de Referência Cultural e, em 1976, o Conselho Nacional de Cinema (Concine). Em 1978, surge mais uma estrutura para coordenar os assuntos culturais do MEC, a Secretaria de Assuntos Culturais (SAC), que em 1981 é alçada a Secretaria da Cultura da Presidência da República, ganhando em importância e alocação de recursos (MOISÉS, 1998).
} 
A Constituição Federal de 1988 reorienta as noções de cultura e de patrimônio, que abandonam a estreita vinculação com "fatos memoráveis da História do Brasil" atrelada firmemente ao passado, incorporando o sentido de "patrimônio cultural" e a memória dos grupos sociais. O texto constitucional enfatiza o direito de acesso à cultura, a legitimidade da diversidade cultural brasileira e o papel do Estado nessa construção, além de ampliar a capacidade de financiamento de estados e municípios. Entretanto, os ventos liberalizantes e a ausência de um pacto federativo entre as instâncias de governo levaram grande parte dos estados e municípios a mimetizarem a política baseada em incentivos fiscais, em mecanismos de renúncia fiscal e numa estrutura de gerenciamento de recursos similar à verificada em nível federal.

Em 1990, o governo Collor comandou um retrocesso na construção das políticas e das instituições culturais brasileiras. Foram extintos o então recém-criado Ministério da Cultura - que ficou vinculado à Presidência da República como secretaria - e órgãos como a Embrafilme, o Concine e o Instituto Nacional do Livro, entre outros, além de fundidos vários órgãos, como a Funarte, transformada em Instituto Brasileiro de Arte e Cultura (Ibac). O objetivo declarado era a contenção dos gastos públicos, num quadro econômico instável. Isso de fato aconteceu, ao ser reduzido o orçamento federal para a cultura em mais de 50\% em relação ao período anterior, situação agravada pela desativação da Lei Sarney.

A sociedade resistia ao desmonte institucional ao exigir a recomposição dos instrumentos políticos já obtidos, o que levou à formulação, em 1991, de um projeto substitutivo da Lei Sarney, em vigor até hoje. A destituição do presidente Collor de suas funções em um complexo processo de impeachment pelo Congresso Nacional permitiu o início da reconstrução da estrutura institucional da cultura.

Em 1993 é retomado o diálogo entre o governo e a sociedade. É recriado o Conselho Nacional de Política Cultural e são resgatadas as ações do Estado na cultura:

retomou-se, com a criação dessas instituições, a tendência expressa em meados da década anterior, pelo surgimento de uma estrutura mais democrática de administração cultural ou, pelo menos, uma estrutura que previa a consulta entre o Estado e a sociedade civil. Tais passos, após o vendaval representado por Collor, foram um começo, mas, de fato, foi somente no governo seguinte que esses órgãos e mecanismos de fomento começaram a ter papel relevante para as políticas culturais. (MOISÉS, 1998, p.42)

O governo de Fernando Henrique Cardoso teve como marca o discurso da democratização da gestão da cultura, do acesso aos bens culturais, mas usando como meio a maximização da efetividade dos mecanismos de fomento, previstos na legislação de incentivo. A política desse período desejava consolidar outra forma de articular as relações entre o Estado, o mercado e os produtores culturais. As tentativas de democratização das relações entre o Estado e a sociedade - com a recriação, por exemplo, do CNPC, das câmaras setoriais ou da Comissão do Cinema - esbarravam, em última instância, no crescente domínio do mercado, na definição das linhas de ação para a cultura com base em critérios mercadológicos que alijavam da alocação dos recursos os territórios culturais locais espalhados pelo país.

\section{Construção e institucionalização do Sistema Nacional de Cultura}

Um sistema de cultura de amplitude nacional, que respeite a pluralidade e a dispersão espacial da cultura brasileira, é fruto de um processo histórico de luta, política e social, pela preservação das mais variadas formas de expressão artístico-cultural - das regiões distantes dos grandes centros urbanos do Sudeste ou de segmentos da população historicamente excluídos - que formam a dívida sociocultural do Brasil e nunca foram protagonistas das políticas governamentais.

O Sistema Nacional de Cultura é gerado nesse processo histórico no qual são enfrentadas a centralização crônica das políticas e atuações na cultura, a desvalorização da cultura que se constrói localmente no território nacional e o desconhecimento da diversidade de expressões que povoa o país. É também alimentado pela 
observação da experiência que emerge da construção do Sistema Nacional de Saúde (que deu origem ao atual SUS), expressa pela primeira vez no documento A Imaginação a Serviço do Brasil (COLIGAÇÃO..., 2002), que congregava propostas e diretrizes para a área.

O documento programático da coligação vencedora das eleições de 2002 propunha então elementos novos em relação ao histórico das políticas culturais no Brasil: de um lado, a visão ampliada de cultura que declara o respeito à diversidade cultural como a marca da identidade nacional e, de outro, maior abrangência e formulação democrática das políticas públicas e de gestão da cultura:

[...] É essencial, nessas condições, realizar um amplo processo de inclusão cultural, garantindo, de forma progressiva, o acesso de toda a cidadania à produção e fruição cultural, bem como a livre circulação de ideias e de formas de expressão artística. [...]

A lógica da homogeneização nos oprime. [...] Como formular um projeto de Políticas Públicas de Cultura que contemple esse mosaico imperfeito? (COLIGAÇÃO..., 2002, p.8.)

Entre os eixos de atuação assinalados no documento estão a Cultura como política de Estado, a Economia da cultura, a Gestão democrática, o Direito à memória, a Cultura e comunicação e as Transversalidades das políticas públicas de cultura, que apontam para a abrangência que a ação política na cultura deverá ter. De um modo transversal, a ação política no universo da cultura se erige como um instrumento de combate à exclusão social por meio da "[...] abertura democrática dos espaços públicos aos nossos criadores populares e pela 'inclusão da Cultura na cesta básica' dos brasileiros" (COLIGAÇÃO..., 2002, p.10). Assim, ainda que propondo uma forte atuação do Estado na área, caracteriza-a como uma atuação indutora de uma gestão democrática. É clara, na proposta, a marca da experiência adquirida na construção das políticas para a saúde, assistência social e educação das quais os quadros do PT já haviam participado.

A proposta não afasta a ação política na cultura do desenvolvimento econômico do país, ao indicar o necessário entendimento da cultura com o turismo e o desenvolvimento tecnológico, entre outros, nomeadamente para a geração de emprego e renda. Entretanto, ao fazê-lo, atrela as ações à política, por intermédio de um sistema articulado nacionalmente, distanciando-se tanto do assistencialismo como da condução dos rumos pelo mercado, tradição das políticas culturais no Brasil:

Qualquer política de cultura a ser adotada pelo país, deve garantir a abertura dos canais institucionais e financeiros, por meio da constituição do Sistema Nacional de Política Cultural, a amplos setores tradicionalmente atendidos pelas políticas de recorte social ou assistencialista. (COLIGAÇÃO..., 2002, p.16)

A construção e instauração do Sistema Nacional de Cultura é a principal meta política do Ministério da Cultura. No entanto, pela sua própria lógica, isso só pode se concretizar a partir da mobilização nacional dos dirigentes estaduais e municipais da cultura e da sociedade civil organizada.

As primeiras questões que se colocam são a formulação da Política Nacional de Cultura e a discussão sobre o papel do Estado na gestão pública da cultura e no modo de formular estratégias e políticas. A cultura distinguese dos setores da saúde, da assistência social e da educação formal, por ser produzida por uma infinidade de pessoas, espalhadas pelos lugares onde vivem e por meio das mais variadas linguagens. Todas estas linguagens são legítimas por representarem as formas de expressão de identidade de cada um e de cada grupo, em cada lugar. Ao Estado, portanto, não pode caber o papel de produtor da cultura, mas

o de garantir a preservação do patrimônio cultural e o acesso universal aos bens e serviços culturais ou o de proteger e promover a sobrevivência e desenvolvimento de expressões culturais tradicionais, que dificilmente seria assumido pelo setor privado. (COLIGAÇÃO LULA PRESIDENTE, 2002, p.6).

O foco na dimensão simbólica da cultura se expressa na manifestação da necessidade de preservar a diversidade das expressões culturais. Entretanto, é na configuração das estruturas, dos processos de decisão e na 
universalização do acesso aos bens e serviços culturais que irá se expressar a dimensão cidadã na nova política. É pela promoção da cultura como elemento constitutivo do desenvolvimento econômico sustentável que se perceberá sua dimensão econômica. Esses três vetores - o simbólico, a cidadania e a economia -, que dão forma à Política Nacional de Cultura, estão igualmente inscritos na proposta do Sistema Nacional de Cultura (SNC), aprovada pelo Conselho Nacional de Política Cultural (CNPC) ${ }^{7}$ e cujo texto está atualmente em tramitação no Congresso Nacional. Esse documento se origina no Ministério da Cultura. No entanto, a redação apresentada ao Congresso foi debatida e modificada por outras instâncias do governo federal, pelo Fórum de Secretários e Dirigentes Estaduais de Cultura e pelo Fórum de Secretários e Dirigentes de Cultura das Capitais, que representaram, no processo inicial de construção da proposta do SNC, o núcleo embrionário do próprio Sistema.

É bastante razoável que as experiências e os modelos que anteriormente no Brasil articularam outras políticas públicas de grande complexidade, tenham sido referências para a proposição que norteia o SNC. A construção do Sistema Único de Saúde (SUS) é sua principal referência, que remonta a 1941 quando foi realizada a $1^{\underline{a}}$ Conferência Nacional de Saúde (CNS). Desde então, o longo caminho percorrido passou pela instalação do Sistema Nacional de Saúde em 1975, pela Reforma Sanitária e o Financiamento Setorial em 1986, pela declaração da saúde como direito de todos e dever do Estado inscrita na Constituição Federal em 1988 e, nesse mesmo ano, pela implantação do SUS. Em 1992, na $9^{\text {a }}$ CNS, o lema foi a descentralização e a democratização do conhecimento e a municipalização das ações. Em 2007, a 13ª e última CNS reafirma a saúde e a qualidade de vida como uma política de Estado e vetor de desenvolvimento. Poderemos perceber nas linhas que se seguem, como a construção do SNC aproveita as experiências vividas, os acertos e as dificuldades da construção da política nacional de saúde para traçar o seu próprio caminho, ajustando-o às especificidades da cultura e ao tempo em que o SNC se inicia.

O conceito de sistema está na raiz da abordagem da problemática complexa de articular uma política nacional para um campo legitimamente plural e diverso -, na qual interajam articuladamente os entes federativos e a sociedade civil organizada; todos como agentes ativos e autônomos na formação da política e das estratégias de ação. Esse sistema será composto, portanto, de uma parte "dura" e de maior perenidade, constituída pelas leis e normativas que o estruturam e do conjunto da infraestrutura cultural, e de uma parte "mole" e impermanente, onde reside o exercício da política e o jogo que lhe é próprio da negociação, dos acordos, estratégias e pactos.

A partir dessa conceituação, o Sistema proposto deverá ter sua estrutura assente em órgãos gestores instituídos e permanentes, nos três níveis federativos, e em instâncias de articulação, de pactuação e de deliberação. Os elementos estáveis do Sistema são os órgãos gestores da cultura (MinC, secretarias estaduais e municipais de Cultura), as conferências de Cultura, os conselhos de Política Cultural e os sistemas setoriais de Cultura. As instâncias da política - isto é, da articulação, pactuação e deliberação - são as conferências Nacional, estaduais, Distrital e municipais de Cultura; os conselhos Nacional, estaduais, Distrital e municipais de Política Cultural; os conselhos setoriais Nacional, estaduais, Distrital e municipais; as comissões Nacional, estaduais, Distrital e municipais de Fomento e Incentivo à Cultura; a Comissão Intergestores Tripartite e as comissões intergestores bipartites.

Os conselhos de Política Cultural e as conferências nos três níveis federativos são os principais espaços de participação social e de intervenção política para a formulação das políticas que deverão nortear a ação dos órgãos do Sistema. A I Conferência Nacional de Cultura (CNC) ocorrida em 2005, foi orientada pelos eixos temáticos: 1) Gestão pública da cultura; 2) Economia da cultura; 3) Patrimônio cultural; 4) Cultura é cidadania e democracia e 5) Comunicação é cultura. Dela participaram 1.158 municípios - que realizaram um total de

\footnotetext{
${ }^{7}$ O CNPC é um órgão colegiado - integrante da estrutura básica do Ministério da Cultura -, constituído em 2005 e instalado em 2007 , que propõe a formulação de políticas públicas para a cultura e, para isso, a articulação dos diferentes níveis de governo e da sociedade civil organizada. É composto por 46 titulares: 21 representantes dos poderes públicos federal, estadual e municipal; 17 representantes dos segmentos artístico-culturais; cinco representantes de entidades acadêmicas, empresariais, fundações e institutos e por três representantes de entidades de notório saber da área cultural indicados pelo ministro da Cultura.
} 
438 conferências municipais e intermunicipais -, 19 estados e o Distrito Federal. Na etapa municipal de preparação da II CNC, ${ }^{8}$ participaram 50\% dos municípios (BRASIL, 2009b) cujos debates foram orientados pelos eixos: 1) Produção simbólica e diversidade cultural; 2) Cultura, cidade e cidadania; 3) Cultura e desenvolvimento sustentável; 4) Cultura e economia criativa e 5) Gestão e institucionalidade da cultura.

Assim como a área da Saúde e da Assistência Social, que possuem arranjos muito complexos de atuação, envolvendo as três esferas federativas e a sociedade, a Cultura precisa organizar sistemicamente suas políticas e recursos, por meio de articulação e pactuação das relações intergovernamentais, com instâncias de participação da sociedade, de forma a dar um formato político-administrativo mais estável e resistente às alternâncias de poder (BRASIL, 2009a, p.4).

O SNC envolve, desse modo, sistemas organizativos e institucionalizados nos três níveis federativos, numa articulação institucional regulada por normativas, instrumentos, aparatos e negociações imprescindíveis.

Os principais instrumentos de gestão, ferramentas organizacionais do Sistema nos três níveis de governo, são os planos de Cultura, o Sistema Orçamentário, o Sistema de Informações e Indicadores Culturais e o Relatório Anual de Gestão. Por meio deles é que poderão ser efetivamente executadas as políticas e estratégias formadas e pactuadas na complexa rede do Sistema, com o indispensável suporte de uma política de financiamento suficiente e estável.

O financiamento público da cultura é composto pelo orçamento do Ministério da Cultura, pelo Programa Nacional de Incentivo à Cultura (Pronac), que envolve o Fundo Nacional de Cultura (FNC), e por dois fundos específicos para atividades audiovisuais, o Fundo Setorial do Audiovisual e o Fundo de Financiamento da Indústria Cinematográfica Nacional (Funcines). Entretanto, pela proposta do SNC ora em tramitação no Congresso Nacional, bem como em razão da Proposta de Emenda à Constituição (PEC) $n^{0}$ 150/2003, que instituirá, quando aprovada, novos percentuais de arrecadação ( $2 \%$ da União, $1,5 \%$ dos estados e $1 \%$ dos municípios) para a área da cultura, caberá ao FNC o papel de principal mecanismo de financiamento público da cultura.

O estabelecimento de critérios de repartição de receitas que atenda ao princípio federativo é o ponto nodal que deve nortear a gestão das receitas do FNC. A experiência de outros sistemas de políticas públicas induz ao raciocínio que aponta para a distribuição mediante transferências, vinculadas (obrigatórias) ou voluntárias. As primeiras, por sua vez, devem se estabelecer segundo critérios que levem em consideração indicadores diversos, que possam contribuir para a formulação de um "índice" unificado que aponte para a correta e justa distribuição de receitas entre as regiões, estados e municípios (BRASIL, 2009a, p.35).

Os referidos critérios de repartição e as transferências de recursos para estados e municípios deverão ser negociados e pactuados na Comissão Intergestores Tripartite (CIT) e nas Comissões Intergestores Bipartites (CIB) ${ }^{9}$

Completam a estrutura do Sistema em construção o Sistema Nacional de Informações e Indicadores Culturais e a Política Nacional de Formação na Área da Cultura. O primeiro - por meio das informações coletadas, da sistematização dos dados e da construção dos indicadores - oferecerá sustentação à formulação das estratégias, à definição de prioridades e à gestão dos processos que ordenam o Sistema, nomeadamente, dos critérios de repartição dos recursos. O segundo dará suporte à formação da massa crítica indispensável a um Sistema que só

${ }^{8}$ Em 30 de outubro de 2009 foi concluída a etapa municipal, que incluiu conferências municipais e intermunicipais, pré-conferências setoriais e conferências livres. Até o final de dezembro do mesmo ano deverão ser realizadas as conferências estaduais que definirão os delegados para a CNC.

${ }^{9}$ A CIT é composta paritariamente por representantes do MinC, do conjunto dos secretários e dirigentes estaduais de Cultura e dos secretários e dirigentes municipais de Cultura, enquanto a CIB encerra a mesma lógica como articuladora entre o gestor estadual e os gestores municipais. 
poderá ser uma efetiva contribuição para a reforma do Estado brasileiro, no tocante a uma gestão democrática e a uma finalidade substantiva, se promover a compreensão crítica dos envolvidos e uma ampla participação qualificada.

\section{Dinâmica, infraestrutura e Institucionalidade da cultura na região Sul}

As informações disponibilizadas pelo IBGE acerca da cultura no país podem nos permitir importantes análises sobre a construção do Sistema Nacional de Cultura e indicar as deficiências que deverão ser enfrentadas para que os objetivos de tal projeto possam ser alcançados. Nesta análise consideraremos a região Sul e seus estados, por ser a região onde atuamos, comparando-a eventualmente com o cenário brasileiro.

Embora os estados da região apresentem diferenças no que diz respeito à intensidade de atividades culturais, pode-se perceber que um número relevante de municípios em cada estado realiza os diversos tipos de atividades pesquisadas. As diferenças entre os estados não são significativas, tampouco, decisivas, quando se comparam os dados, considerando-se o percentual de municípios que apresentam a atividade ante a totalidade dos municípios de cada estado, como se pode perceber na tabela 1.

Percebe-se a intensidade das manifestações artísticas nos estados, que ocorrem em número expressivo de municípios com atividades e grupos artísticos nos diversos tipos de modalidades relacionadas. Dentre estas, destacam-se os grupos de dança, os corais, os grupos de música e as manifestações tradicionais populares.

Tabela 1 - Municípios da região Sul com grupos artísticos por modalidade

\begin{tabular}{|c|c|c|c|c|c|c|c|c|c|}
\hline & \multicolumn{9}{|c|}{ Municípios } \\
\hline & \multirow[b]{2}{*}{ Total } & \multicolumn{8}{|c|}{ Com grupos artísticos - por modalidade } \\
\hline & & Teatro & $\begin{array}{c}\text { Manifestação } \\
\text { tradicional } \\
\text { popular }\end{array}$ & Cineclube & Dança & Musical & Orquestra & Banda & Coral \\
\hline Brasil & 5.564 & 2.219 & 3.149 & 231 & 3.123 & 2.624 & 638 & 2.962 & 2.498 \\
\hline Sul & 1.188 & 449 & 540 & 40 & 801 & 627 & 111 & 592 & 716 \\
\hline PR & 399 & 179 & 163 & 14 & 229 & 206 & 31 & 177 & 199 \\
\hline $\mathrm{SC}$ & 293 & 96 & 148 & 7 & 228 & 192 & 26 & 135 & 210 \\
\hline $\mathrm{RS}$ & 496 & 174 & 229 & 19 & 344 & 229 & 54 & 280 & 307 \\
\hline
\end{tabular}

Fonte: IBGE (2007).

$\mathrm{Na}$ tabela 3, destacam-se as atividades de artesanato, capoeira e de desenho e pintura, em comparação com o circo e as associações literárias, relatados por um pequeno número de municípios. Embora seja, de certa maneira, senso comum a existência no Brasil de uma grande efervescência cultural, nenhum levantamento, até então, havia proporcionado um conhecimento tão detalhado da situação da cultura no país. Essas informações são fundamentais para que possam ser identificadas certas características das manifestações culturais. Por exemplo, a preponderância da atividade artesanal, presente em 823 municípios da região sul, seguida pela de grupos de dança, corais e grupos musicais, assim como a existência de bandas em 49,8\% dos municípios da região. Há ainda a presença marcante de grupos de manifestação tradicional popular.

Deve-se considerar um dos problemas da base de dados do IBGE: a dependência do conhecimento das Secretarias Municipais acerca da realidade dos municípios que, raramente, é um conhecimento sistemático. É possível, então, que a existência de grupos artísticos seja bem maior do que aquela informada pelas Secretarias. 
Tabela 2 - Municípios da região Sul com grupos artísticos por modalidade

\begin{tabular}{ccccccccccc}
\hline & \multicolumn{10}{c}{ Municípios } \\
\hline & Total & $\begin{array}{c}\text { Associação } \\
\text { literária }\end{array}$ & Capoeira & Circo & $\begin{array}{c}\text { Escola de } \\
\text { samba }\end{array}$ & $\begin{array}{c}\text { Bloco } \\
\text { carnavalesco }\end{array}$ & $\begin{array}{c}\text { Desenho e } \\
\text { pintura }\end{array}$ & $\begin{array}{c}\text { Artes } \\
\text { plásticas e } \\
\text { visuais }\end{array}$ & $\begin{array}{c}\text { Artesanato } \\
\text { (1) }\end{array}$ \\
\hline Brasil & $\mathbf{5 . 5 6 4}$ & $\mathbf{5 2 3}$ & $\mathbf{2 . 7 1 6}$ & $\mathbf{1 6 0}$ & $\mathbf{6 3 2}$ & $\mathbf{1 . 9 0 4}$ & $\mathbf{1 . 4 0 5}$ & $\mathbf{1 . 2 3 4}$ & $\mathbf{3 . 5 8 0}$ \\
\hline Sul & $\mathbf{1 . 1 8 8}$ & $\mathbf{1 1 7}$ & $\mathbf{3 4 4}$ & $\mathbf{3 1}$ & $\mathbf{1 2 2}$ & $\mathbf{2 5 2}$ & $\mathbf{3 2 9}$ & $\mathbf{2 8 3}$ & $\mathbf{8 2 3}$ \\
\hline PR & 399 & 32 & 141 & 23 & 20 & 57 & 125 & 107 & 250 \\
\hline SC & 293 & 28 & 85 & 4 & 18 & 48 & 85 & 72 & 213 \\
\hline RS & 496 & 57 & 118 & 4 & 84 & 147 & 119 & 104 & 360 \\
\hline
\end{tabular}

Fonte: IBGE (2007).

No que diz respeito à existência de equipamentos culturais, destaca-se o número de municípios com bibliotecas públicas $(90,6 \%)$ e estádios ou ginásios poliesportivos (93\%). Embora estes possam ter sua classificação como equipamento cultural questionada, é importante perceber que em municípios desprovidos de outros equipamentos, os ginásios abrigam algumas das atividades culturais, como as apresentações teatrais e musicais, por exemplo. Tanto mais que o número de municípios que dispõem de centros culturais e, sobretudo, de teatros ou salas de espetáculo, assim como de cinemas, é bastante reduzido em comparação com os demais equipamentos. O número insignificante de municípios que dispõem de cinemas já tem sido discutido em muitas publicações que comentaram os dados do IBGE; além disso, é notória a transformação dos cinemas em lojas, igrejas etc. em todo o país.

Tabela 3 - Municípios que relatam a existência de equipamentos culturais na região Sul

\begin{tabular}{cccccccc}
\hline & \multicolumn{7}{c}{ Municípios } \\
\cline { 2 - 9 } & Total & $\begin{array}{c}\text { Bibliotecas } \\
\text { públicas }\end{array}$ & Museus & $\begin{array}{c}\text { Teatro ou salas de } \\
\text { espetáculos }\end{array}$ & Centro cultural & $\begin{array}{c}\text { Com estádios ou ginásios } \\
\text { poliesportivos }\end{array}$ & Cinemas \\
\cline { 2 - 9 } & & Total & Total & Total & Total & Total & Total \\
\hline Brasil & $\mathbf{5 . 5 6 4}$ & $\mathbf{4 . 9 5 5}$ & $\mathbf{1 . 2 1 9}$ & $\mathbf{1 . 1 8 1}$ & $\mathbf{1 . 3 7 8}$ & $\mathbf{4 . 5 8 4}$ & $\mathbf{4 8 2}$ \\
\hline Sul & $\mathbf{1 . 1 8 8}$ & $\mathbf{1 . 0 7 7}$ & $\mathbf{4 2 9}$ & $\mathbf{2 7 4}$ & $\mathbf{3 5 4}$ & $\mathbf{1 . 1 0 6}$ & $\mathbf{9 7}$ \\
\hline PR & 399 & 365 & 86 & 130 & 155 & 286 & 33 \\
\hline SC & 293 & 269 & 114 & 49 & 66 & 438 & 25 \\
\hline RS & 496 & 443 & 229 & 95 & 133 & 39 \\
\hline
\end{tabular}

Fonte: IBGE (2007).

Além de sabermos quantos municípios dispõem de cada tipo de equipamento, também sabemos o número total de equipamentos existentes no estado. Assim, podemos estabelecer uma relação que indica concentração e dispersão de equipamentos por município. Aquele é o caso dos teatros e cinemas e este, o das bibliotecas públicas e centros culturais, o que indica que os equipamentos mais sofisticados e de maior custo de manutenção têm menor interiorização.

A importância da atuação do Estado é revelada pelo número de equipamentos financiados pelo poder público municipal. Os destaques são as bibliotecas públicas, mantidas quase na sua totalidade pelos municípios, assim como os centros culturais, que atingem o percentual de $68 \%$ de manutenção pelo município. Apenas os cinemas não recebem recursos públicos municipais. 
A limitação dos dados não nos permite conhecer as condições dos equipamentos, seu modo de gestão e os profissionais com os quais a equipe de gestão pode contar para a realização das atividades. Esse é um levantamento importante a ser incluído nos sistemas de informação culturais em construção no país.

\section{Tabela 4 - Quantidade de equipamentos culturais na região Sul}

\begin{tabular}{|c|c|c|c|c|c|c|c|c|c|c|c|c|}
\hline & \multicolumn{12}{|c|}{ Municípios com quantidade de equipamentos culturais e mantidos pelo poder público. } \\
\hline & \multirow[t]{2}{*}{ Total } & \multicolumn{2}{|c|}{$\begin{array}{l}\text { Bibliotecas } \\
\text { públicas }\end{array}$} & \multicolumn{2}{|c|}{ Museus } & \multicolumn{2}{|c|}{$\begin{array}{l}\text { Teatro ou sala } \\
\text { de espetáculos }\end{array}$} & \multicolumn{2}{|c|}{ Centro Cultural } & \multicolumn{2}{|c|}{$\begin{array}{l}\text { Estádios ou } \\
\text { ginásios } \\
\text { poliesportivos }\end{array}$} & \multirow{2}{*}{$\begin{array}{c}\text { Cinemas } \\
\text { Quant. }\end{array}$} \\
\hline & & Quant. & PP & Quant. & $\mathrm{PP}$ & Quant. & $\mathrm{PP}$ & Quant. & PP & Quant. & PP & \\
\hline Brasil & 5.564 & 7.048 & 4847 & 2.222 & 967 & 2.495 & 905 & 1.892 & 1.237 & 11.613 & 4.313 & 1.095 \\
\hline Sul & 1.188 & 1.441 & 1.058 & 689 & 373 & 563 & 226 & 474 & 323 & 3.699 & 983 & 223 \\
\hline PR & 399 & 616 & 364 & 151 & 77 & 265 & 122 & 215 & 149 & 1183 & 378 & 67 \\
\hline $\mathrm{SC}$ & 293 & 316 & 257 & 177 & 91 & 91 & 26 & 86 & 53 & 1118 & 246 & 47 \\
\hline $\mathrm{RS}$ & 496 & 509 & 437 & 361 & 205 & 207 & 78 & 173 & 121 & 1398 & 359 & 109 \\
\hline
\end{tabular}

Fonte: IBGE (2007).

PP: mantidos pelo poder público.

\section{A situação da estrutura de governo da cultura nos municíplos da região Sul}

Como discutimos na descrição da trajetória das políticas públicas de cultura no país, o Estado sempre foi um agente forte no campo. Em diversos momentos da história brasileira, sua ação redirecionou os rumos da cultura e de suas instituições; frequentemente, de forma centralizada. A construção do Sistema Nacional de Cultura, assim como a de outros sistemas no país, como o SUS, põe em evidência, através da descentralização almejada, os municípios e sua estrutura de governo. Além disso, implica conhecer e refletir sobre as potencialidades dos governos municipais, a fim de enfrentar os entraves que possam, de alguma forma, impedir sua participação qualificada nas disputas e negociações entre os diferentes agentes.

Os municípios da região sul apresentam, em sua maioria, estruturas de governo para a área da cultura. Essas estruturas são, em grande parte, compartilhadas com outras áreas ou subordinadas a outra secretaria. Em 846 municípios $(72,4 \%)$ da região, a cultura compartilha a estrutura da secretaria com outra área; na maioria das vezes, com a de educação. Além destes, 201 municípios (17,2\%) subordinam uma estrutura voltada para a cultura a uma secretaria de outra área e, $44(3,7 \%)$ a subordinam ao chefe do Executivo. Somente 77 municípios (6,5\%) apresentam uma estrutura exclusivamente voltada à cultura (secretaria exclusiva + fundação pública). Em 51, essa estrutura toma a forma jurídica de fundação pública, compreendida pelo IBGE como o mais moderno tipo de estrutura. Isso significa uma taxa equivalente à nacional, na qual $7 \%$ das estruturas são exclusivas da cultura. Somente 20 municípios $(1,7 \%)$ da região Sul não possuem estrutura para a área. Na sua maioria, são municípios com menos de 20 mil habitantes, ao passo que os municípios mais populosos concentram as fundações ou as secretarias exclusivas.

É interessante perceber que dos municípios brasileiros que contam com uma secretaria exclusiva para a cultura, $11 \%$ situam-se na região sul, assim como $35 \%$ dos que contam com fundações públicas. 
Tabela 5 - Caracterização do órgão gestor da área da cultura

\begin{tabular}{|c|c|c|c|c|c|c|c|c|}
\hline & \multicolumn{8}{|c|}{ Com estrutura na área da cultura, por caracterização do órgão gestor } \\
\hline & Total & Total & $\begin{array}{l}\text { Secretaria } \\
\text { municipal } \\
\text { exclusiva }\end{array}$ & $\begin{array}{c}\text { Secretaria } \\
\text { municipal em } \\
\text { conjunto com } \\
\text { outras políticas }\end{array}$ & $\begin{array}{c}\text { Setor } \\
\text { subordinado a } \\
\text { outra secretaria }\end{array}$ & $\begin{array}{c}\text { Setor } \\
\text { subordinado à } \\
\text { chefia do } \\
\text { Executivo }\end{array}$ & $\begin{array}{c}\text { Fundação } \\
\text { pública }\end{array}$ & $\begin{array}{l}\text { Não possui } \\
\text { estrutura } \\
\text { específica }\end{array}$ \\
\hline Brasil & 5.564 & 5.426 & $236(4,3 \%)$ & $4.007(73,8 \%)$ & $699(12,8 \%)$ & $339(6,2 \%)$ & $145(2,6 \%)$ & $136(2,5 \%)$ \\
\hline Sul & 1.188 & 1.168 & $26(2,2)$ & $846(72,4 \%)$ & $201(17,2 \%)$ & $44(3,7 \%)$ & $51(4,3 \%)$ & $20(1,7 \%)$ \\
\hline PR & 399 & 392 & 16 & 240 & 99 & 21 & 16 & 7 \\
\hline SC & 293 & 287 & 0 & 198 & 45 & 14 & 30 & 6 \\
\hline $\mathrm{RS}$ & 496 & 489 & 10 & 408 & 57 & 9 & 5 & 7 \\
\hline
\end{tabular}

Fonte: IBGE (2007).

A maioria das fundações de cultura tem como atividade principal a promoção de eventos, seguida da divulgação cultural, da formação artística e da administração de equipamentos culturais, entre outras. A preponderância da promoção de eventos como atividade principal da fundação nos permite inferir que o município ainda não desempenha seu papel na construção de políticas públicas para a cultura que permitam uma atuação sistemática, orientada por análises que considerem a situação do município, sua história e sua visão de futuro.

Quando se analisa o nível de instrução do titular do órgão gestor da cultura, percebe-se que $11,3 \%$ dos municípios atribuem essa responsabilidade a gestores com escolaridade até o nível médio. O "fazer cultura" pode prescindir de educação formal e o nível de instrução do gestor (obtido usando estritamente as categorias de educação formal) pode estar associado a esse aparente descompasso. Não obstante os menores municípios registrarem os menores níveis de escolaridade do gestor cultural, o que pode indicar uma dificuldade de obtenção de quadros nesses locais, os dados disponíveis não permitem assegurar tal inferência.

Essa situação deveria nos fazer refletir sobre algo para o qual Matus (1996b) já havia alertado: a precária formação dos governantes na ciência de governar. Para o diagnóstico desta deficiencia poderiam contribuir dados que abrangessem as especificidades da área, de modo a permitir uma intervenção qualificada do futuro Sistema Nacional de Formação em Gestão Cultural. 
Tabela 6 - Nível de instrução do titular do órgão gestor da cultura

\begin{tabular}{cccccccccc}
\hline & \multicolumn{7}{c}{ Nível de instrução do titular do órgão gestor da cultura } \\
\cline { 2 - 10 } & Total & $\begin{array}{c}\text { Ensino } \\
\text { fundamental } \\
\text { incompleto }\end{array}$ & $\begin{array}{c}\text { Ensino } \\
\text { fundamental } \\
\text { completo }\end{array}$ & $\begin{array}{c}\text { Ensino médio } \\
\text { incompleto }\end{array}$ & $\begin{array}{c}\text { Ensino } \\
\text { médio } \\
\text { completo }\end{array}$ & $\begin{array}{c}\text { Ensino superior } \\
\text { incompleto }\end{array}$ & $\begin{array}{c}\text { Ensino } \\
\text { superior } \\
\text { completo }\end{array}$ & $\begin{array}{c}\text { Pós- } \\
\text { graduação }\end{array}$ \\
\hline Brasil & $\mathbf{5 3 8 8}$ & $\mathbf{2 9}$ & $\mathbf{4 4}$ & $\mathbf{9 6}$ & $\mathbf{6 7 8}$ & $\mathbf{5 9 0}$ & $\mathbf{2 . 0 8 5}$ & $\mathbf{1 . 8 6 6}$ \\
\hline Sul & $\mathbf{1 1 6 5}$ & $\mathbf{1 0}$ & $\mathbf{6}$ & $\mathbf{2 0}$ & $\mathbf{9 9}$ & $\mathbf{1 1 2}$ & $\mathbf{3 3 4}$ & $\mathbf{5 8 4}$ \\
\hline PR & 391 & 1 & 2 & 6 & 35 & 24 & 82 & 241 \\
\hline SC & 287 & 3 & 3 & 4 & 17 & 22 & 77 & 161 \\
\hline RS & 487 & 6 & 1 & 10 & 47 & 66 & 175 & 182 \\
\hline
\end{tabular}

Fonte: IBGE (2007).

No que diz respeito aos instrumentos de gestão, $62,8 \%$ dos municípios da região Sul têm política municipal de cultura; um número bastante expressivo, acima da média nacional, mas que demonstra, também, que muitos municípios ainda não dispõem de um instrumento direcionador da ação pública na cultura. É importante destacar que $41,2 \%$ atribuem como objetivo principal da política a transformação da cultura em um componente básico para a qualidade de vida da população, seguido pelo de participação social, num registro semelhante à tendência nacional. No entanto, o propósito de conseguir maior participação social nos projetos culturais não é acompanhado de uma ênfase na descentralização da produção cultural nem da democratização da gestão. Isso nos leva a supor que participação social pode ser confundida com participação passiva nas manifestações culturais.

Tabela 7 - Objetivos das políticas municipais de cultura

\begin{tabular}{|c|c|c|c|c|c|c|c|c|c|c|c|}
\hline & \multicolumn{11}{|c|}{ Municípios } \\
\hline & \multicolumn{11}{|c|}{ Com política municipal de cultura } \\
\hline & \multirow[b]{2}{*}{ Total } & \multirow[b]{2}{*}{ Total } & \multicolumn{8}{|c|}{ Objetivos principais da política } & \multirow[b]{2}{*}{ Outros } \\
\hline & & & $\begin{array}{l}\text { Cultura } \\
\text { como } \\
\text { compo- } \\
\text { nente da } \\
\text { qualidad } \\
\text { e de vida }\end{array}$ & $\begin{array}{l}\text { Ampliar } \\
\text { participação } \\
\text { social nos } \\
\text { projetos } \\
\text { culturais }\end{array}$ & $\begin{array}{l}\text { Dinamizar } \\
\text { as } \\
\text { atividades } \\
\text { culturais }\end{array}$ & $\begin{array}{l}\text { Integrar } \\
\text { cultura ao } \\
\text { desenvol- } \\
\text { vimento } \\
\text { local }\end{array}$ & $\begin{array}{l}\text { Preservar o } \\
\text { patrimônio } \\
\text { histórico, } \\
\text { artístico- } \\
\text { cultural }\end{array}$ & $\begin{array}{l}\text { Descentra- } \\
\text { lizar a } \\
\text { produção } \\
\text { cultural }\end{array}$ & $\begin{array}{l}\text { Sobrevivên- } \\
\text { cia das } \\
\text { tradições } \\
\text { culturais } \\
\text { locais }\end{array}$ & $\begin{array}{l}\text { Democra- } \\
\text { tizar } \\
\text { gestão } \\
\text { cultural }\end{array}$ & \\
\hline Brasil & 5.564 & 3.224 & 2.057 & 605 & 435 & 64 & 48 & - & 13 & - & 2 \\
\hline Sul & 1.188 & 747 & 490 & 133 & 100 & 15 & 6 & - & 3 & - & - \\
\hline PR & 399 & 223 & 153 & 34 & 30 & 1 & 3 & - & 2 & - & - \\
\hline $\mathrm{SC}$ & 293 & 201 & 134 & 34 & 29 & 2 & 2 & - & - & - & - \\
\hline RS & 496 & 323 & 203 & 65 & 41 & 12 & 1 & - & 1 & - & - \\
\hline
\end{tabular}

Fonte: IBGE (2007).

As ações implementadas nos 24 meses anteriores à coleta de dados tornam concretos os principais objetivos das políticas municipais de cultura indicados. Isso se verifica na medida em que dão preferência à promoção de atividades culturais, à manutenção de oficinas e cursos, à garantia de acesso às atividades e à divulgação da produção cultural local, num indicativo do sentido de lazer como qualidade de vida, oferecido à população por meio das atividades culturais. 
Tabela 8 - Municípios com política municipal de cultura (por ações mais frequentes implementadas nos últimos 24 meses)

\begin{tabular}{|c|c|c|c|c|c|c|c|c|c|c|}
\hline \multirow[b]{4}{*}{ Total } & \multirow[b]{4}{*}{ Total } & \multicolumn{7}{|c|}{ Municípios } & \multicolumn{2}{|l|}{2} \\
\hline & & \multicolumn{7}{|c|}{ Com política municipal de cultura } & 3 & \\
\hline & & \multicolumn{8}{|c|}{ Ações implementadas nos últimos 24 meses } & \multirow[b]{2}{*}{$\begin{array}{l}\text { Promoção } \\
\text { do uso } \\
\text { comunitário } \\
\text { dos espaços } \\
\text { culturais }\end{array}$} \\
\hline & & $\begin{array}{l}\text { Promoção } \\
\text { de } \\
\text { atividades } \\
\text { culturais } \\
\text { voltadas } \\
\text { para } \\
\text { públicos } \\
\text { variados }\end{array}$ & $\begin{array}{l}\text { Manutenção } \\
\text { de oficinas } \\
\text { e cursos na } \\
\text { área } \\
\text { artístico- } \\
\text { cultural }\end{array}$ & $\begin{array}{l}\text { Garantia } \\
\text { de acesso } \\
\text { às } \\
\text { atividades } \\
\text { culturais }\end{array}$ & $\begin{array}{l}\text { Divulgação } \\
\text { da } \\
\text { produção } \\
\text { cultural } \\
\text { local }\end{array}$ & $\begin{array}{l}\text { Incentivo à } \\
\text { formação e } \\
\text { manutenção } \\
\text { de grupos } \\
\text { de cultura } \\
\text { tradicionais }\end{array}$ & $\begin{array}{c}\text { Divulgação } \\
\text { do } \\
\text { patrimônio, } \\
\text { manutenção } \\
\text { e } \\
\text { revitalização } \\
\text { de áreas } \\
\text { históricas }\end{array}$ & $\begin{array}{l}\text { Manutenção } \\
\text { de } \\
\text { calendário } \\
\text { de festas } \\
\text { tradicionais } \\
\text { populares }\end{array}$ & $\begin{array}{c}\text { Difusão } \\
\text { ampla das } \\
\text { informações } \\
\text { culturais }\end{array}$ & \\
\hline Brasil & 5.564 & 3.224 & 2.876 & 2.751 & 2.321 & 2.423 & 2.212 & 2.038 & 1.841 & 1.939 \\
\hline Sul & 1188 & 747 & 692 & 612 & 547 & 531 & 529 & 503 & 471 & 442 \\
\hline PR & 399 & 223 & 208 & 173 & 150 & 132 & 156 & 159 & 146 & 126 \\
\hline $\mathrm{SC}$ & 293 & 201 & 182 & 158 & 146 & 156 & 142 & 143 & 128 & 125 \\
\hline $\mathrm{RS}$ & 496 & 323 & 302 & 281 & 251 & 243 & 231 & 201 & 197 & 191 \\
\hline
\end{tabular}

Fonte: IBGE (2007).

Enquanto 62,8\% dos municípios da região têm política municipal de cultura, os conselhos municipais de Cultura estão presentes em apenas $15 \%$ deles; percentual próximo da média nacional. Uma vez que um Conselho Municipal de Cultura é um elemento estruturante do sistema em nível municipal e onde mais se efetiva a participação da sociedade civil, podemos supor que em boa parte dos municípios a formulação das políticas estará centralizada no Executivo municipal e, de qualquer forma, sem participação da sociedade. Isso pode indicar um viés autoritário e centralizador da tradição política brasileira a ser enfrentado pelo Sistema Nacional de Cultura.

Tabela 9 - Municípios com Conselho Municipal de Cultura

\begin{tabular}{cccccc}
\hline & & \multicolumn{4}{c}{ Municípios } \\
\cline { 3 - 6 } & & & Dispõe de um Conselho Municipal de Cultura \\
\cline { 3 - 6 } & Total & & \multicolumn{3}{c}{ Proporção de representação } \\
\cline { 3 - 6 } & & & Paritário & $\begin{array}{c}\text { Predomina a } \\
\text { governamental }\end{array}$ & $\begin{array}{c}\text { Predomina a } \\
\text { sociedade civil }\end{array}$ \\
\hline Brasil & $\mathbf{5 . 5 6 4}$ & $\mathbf{9 4 8}$ & $\mathbf{5 8 6}$ & $\mathbf{1 0 3}$ & $\mathbf{2 5 9}$ \\
\hline Sul & $\mathbf{1 . 1 8 8}$ & $\mathbf{1 7 9}$ & $\mathbf{8 3}$ & $\mathbf{1 9}$ & $\mathbf{7 7}$ \\
\hline PR & 399 & 33 & 11 & 5 & 17 \\
\hline SC & 293 & 48 & 22 & 4 & 16 \\
\hline RS & 496 & 98 & 50 & 44 \\
\hline
\end{tabular}

Fonte: IBGE (2007).

Nos municípios que constituíram seus conselhos, a participação da sociedade civil aparece com representação significativa, sendo paritária em $46 \%$, com predominância da sociedade civil em $43 \%$. Com a aprovação da PEC $\mathrm{n}^{\mathrm{o}}$ 416/2005, que institui o SNC, essa tendência terá força de lei. o que deverá promover a partir de 2010 uma mudança significativa e acelerada no perfil dos atores que nos municípios irão decidir sobre políticas, planos de execução e critérios de distribuição de recursos.

Tabela 10 - Municípios com Plano Municipal ou Intermunicipal de cultura 


\begin{tabular}{|c|c|c|c|c|c|}
\hline & \multicolumn{5}{|c|}{ Municípios } \\
\hline & \multirow{3}{*}{ Total } & \multicolumn{4}{|c|}{$\begin{array}{l}\text { Com Plano Municipal ou Intermunicipal de Cultura, por fase e } \\
\text { forma de elaboração }\end{array}$} \\
\hline & & \multirow[b]{2}{*}{ Total } & \multicolumn{2}{|c|}{ Fase } & \multirow{2}{*}{$\begin{array}{l}\text { Elaborado com } \\
\text { participação da } \\
\text { sociedade civil }\end{array}$} \\
\hline & & & Em implantação & Em execução & \\
\hline Brasil & 5.564 & 646 & 433 & 213 & 538 \\
\hline Sul & 1.188 & 123 & 81 & 42 & 102 \\
\hline PR & 399 & 39 & 27 & 12 & 30 \\
\hline $\mathrm{SC}$ & 293 & 37 & 23 & 14 & 32 \\
\hline $\mathrm{RS}$ & 496 & 47 & 31 & 16 & 40 \\
\hline
\end{tabular}

Fonte: IBGE (2007).

A consolidação da política na forma de Plano Municipal ou Intermunicipal de Cultura é realizada por 10\% dos municípios da região, dos quais $83 \%$ com participação da sociedade civil. No entanto, em apenas $34 \%$ desses municípios o plano já foi implantado, enquanto nos demais $66 \%$ ainda está em fase de implantação.

Seguindo a média nacional, apenas $5,3 \%$ dos municípios contam com legislação de fomento à cultura. Porém, num indicador ainda menor, apenas $2 \%$ desse fomento é financiamento público direto, enquanto para $3 \%$, o financiamento ocorre por meio de incentivos fiscais. A ausência de marco legal contrasta com a informação de que $47 \%$ do financiamento das atividades culturais nos municípios brasileiros é fruto de transferências do nível municipal de governo. É pertinente questionarmos os critérios que determinam esse financiamento à cultura e antever a mudança que deverá ocorrer, para que a partir da implantação dos sistemas municipais de cultura, todos os financiamentos - com recursos próprios ou transferências federais - sejam pautados pela transparência e democraticamente determinados.

Tabela 11 - Municípios da Região Sul com legislação de fomento à cultura

\begin{tabular}{|c|c|c|c|c|c|c|}
\hline & \multirow{4}{*}{ Total } & \multicolumn{4}{|c|}{ Municípios } & \\
\hline & & \multicolumn{5}{|c|}{ Com legislação municipal de fomento à cultura, por algumas características } \\
\hline & & \multirow[b]{2}{*}{ Total } & \multirow{2}{*}{$\begin{array}{c}\text { Legislação } \\
\text { aplicada nos } \\
\text { últimos dois } \\
\text { anos }\end{array}$} & \multicolumn{2}{|c|}{ Objeto da legislação } & \multirow[b]{2}{*}{ Outros } \\
\hline & & & & $\begin{array}{c}\text { Incentivo fiscal pessoa física ou } \\
\text { jurídica }\end{array}$ & Financiamento público & \\
\hline Brasil & 5.564 & 310 & 163 & 215 & 117 & 45 \\
\hline Sul & 1.188 & 64 & 36 & 37 & 26 & 9 \\
\hline PR & 399 & 28 & 13 & 20 & 11 & 1 \\
\hline $\mathrm{SC}$ & 293 & 16 & 9 & 8 & 6 & 6 \\
\hline $\mathrm{RS}$ & 496 & 20 & 14 & 9 & 9 & 2 \\
\hline
\end{tabular}

Fonte: IBGE (2007). 
Apenas 4\% dos municípios da região Sul contam com Fundo Municipal de Cultura, cuja gestão, na maioria das vezes, cabe ao secretário ou a um técnico da área (ou mesmo de outra área). Apenas $28,8 \%$ têm gestão colegiada com participação da sociedade civil.

\section{Tabela 12 - Municípios da Região Sul com Fundo Municipal de Cultura}

\begin{tabular}{|c|c|c|c|c|c|c|c|c|}
\hline & \multicolumn{8}{|c|}{ Municípios } \\
\hline & \multirow[b]{3}{*}{ Total } & \multicolumn{7}{|c|}{ Com existência do Fundo Municipal de Cultura } \\
\hline & & & \multirow[b]{2}{*}{$\begin{array}{c}\text { Fundo } \\
\text { exclusivo } \\
\text { da cultura }\end{array}$} & \multicolumn{5}{|c|}{ A administração é feita por } \\
\hline & & & & $\begin{array}{c}\text { Colegiado } \\
\text { com } \\
\text { participação } \\
\text { da sociedade } \\
\text { civil }\end{array}$ & $\begin{array}{c}\text { Colegiado } \\
\text { sem } \\
\text { participação } \\
\text { da sociedade } \\
\text { civil }\end{array}$ & $\begin{array}{c}\text { Secretário } \\
\text { ou técnico } \\
\text { de outra } \\
\text { área }\end{array}$ & $\begin{array}{c}\text { Secretário } \\
\text { ou técnico } \\
\text { da área }\end{array}$ & Outros \\
\hline Brasil & 5.564 & 285 & 255 & 97 & 17 & 53 & 69 & 49 \\
\hline Sul & 1.188 & 52 & 45 & 15 & 3 & 6 & 15 & 13 \\
\hline PR & 399 & 13 & 12 & 2 & - & 2 & 4 & 5 \\
\hline $\mathrm{SC}$ & 293 & 10 & 10 & 2 & - & 2 & 5 & 1 \\
\hline $\mathrm{RS}$ & 496 & 29 & 23 & 11 & 3 & 2 & 6 & 7 \\
\hline
\end{tabular}

Fonte: IBGE (2007).

A PEC n⿳0 416/2005 prevê que as transferências federais de recursos só poderão ocorrer se estados e municípios tiverem instituídos seus sistemas estaduais e municipais de Cultura. Assim os estados e municípios deverão ter conselhos, planos, fundos e orçamentos para a cultura. Diante da quase inexistência desses instrumentos e órgãos atualmente, pode-se prever, a partir de 2010, as dificuldades que quase mil municípios na região (e uma proporção igual no país) enfrentarão para construírem a trama institucional indispensável para executar a política e gerenciar a área da cultura nos novos moldes.

Na região Sul, objeto preferencial deste estudo, desperta curiosidade o fato de que 62,8\% dos municípios indiquem ter políticas municipais de cultura, enquanto apenas 15\% têm um Conselho Municipal de Cultura, $10 \%$ têm plano de cultura, 5\% contam com legislação própria e somente 4\% disponham de um Fundo Municipal de Cultura. Que política é instituída sem participação colegiada, na qual a sociedade não intervém e tampouco se consubstancia em leis nem em ferramentas de gestão que apoiem as ações previstas nos planos?

Esses dados apontam para a ampla envergadura da mudança que precisará ocorrer na imensa maioria dos municípios do país para desconstruir a tradição de centralização, de personalismo na tomada de decisões, de informalidade, de amadorismo na gestão e de casuísmo na alocação de recursos. É nesse cenário, que a vivência nos assegura e os dados insinuam, que o Sistema Nacional de Cultura deverá ser edificado e institucionalizado. Isso deverá ocorrer em bases democráticas e participativas, inscritas em marco legal e que orientem instrumentos formais de gestão, acompanhamento e avaliação.

Assim, parece evidente a importância da elaboração de um sistema de informações efetivamente competente e ajustado à especificidade da área. Tal sistema deverá permitir conhecer, mais do que intuir, os retratos e as dinâmicas verificadas no campo, dando suporte a um conjunto de indicadores que possibilitem a formulação de projeções e de estratégias. Por outro lado, parece igualmente indispensável contar com um sistema de formação na área cultural que, estando ao alcance dos agentes sociais intervenientes nos sistemas locais, dê suporte cognitivo e de aprendizagem para a transformação na qual estes deverão atuar.

Esse universo deverá ser amplo, levando-se em conta a evolução observada desde 2005. Na ocasião, 25,6\% dos municípios da região Sul realizaram suas conferências municipais ou intermunicipais para participarem da I 
Conferência Nacional de Cultura. Em 2006, 39,8\% dos municípios indicaram adesão ao SNC, embora somente 18,2\% tivessem ciência da elaboração do Plano Nacional de Cultura. No entanto, em outubro de 2009, na preparação para a $2 \mathrm{a}$ CNC que ocorrerá em 2010, 51,5\% dos municípios da região realizaram conferências municipais ou intermunicipais de Cultura e elegeram delegados para as conferências estaduais que irão ocorrer até ao final do ano. Se, de um lado, o envolvimento crescente dos municípios indica a anteriormente referida adesão ao Sistema, por outro, aponta para a ampla envergadura do processo de mudança e a indispensável estrutura de suporte a ser instituída.

\section{Discussão a título de considerações (quase) finals}

A discussão que parece caber aqui, a partir da análise da proposta de construção de um sistema nacional e da descrição e interpretação dos dados existentes de uma região do país, diz respeito à opção sobre elementos e critérios que devem ter prevalência sobre outros nas diversas etapas do processo nacional que relatamos, diante do cenário regional que descrevemos.

Argumentamos que a hora é de disputa no campo das ideias para, sob a prioritária valorização dos elementos políticos e sociais do processo, definir princípios educativos, eixos formativos, métodos de abordagem das problemáticas e conceitos nucleares que definirão a organicidade da trama.

Contrariando a famosa frase de Pelé de que "o povo não sabe votar", defendemos que todos, nos mais recônditos espaços locais do país, sabem participar porque sabem almejar um futuro desenhado pelo seu olhar do mundo. O pensador palestino Edward Said lutou, em sua obra Orientalismo, para demonstrar que a subordinação ocorre pelo poder de determinar o que é significativo sobre "o outro" e colocá-lo "em seu lugar".

Assim, consideramos que há que se acompanhar este tempo para produzir reflexões, de modo que o exercício democrático da gestão e da formação das políticas de cultura pela sociedade civil não se transforme, neste processo, em legitimação dos interesses das forças sociais contrárias. Exemplo disso está na construção e manutenção de um sistema de informações que não seja uma fotografia, mas ao invés disso, capture a cultura como um processo e permita a percepção da sua dinâmica. Só assim as informações poderão, de fato, servir aos agentes envolvidos na construção de políticas efetivas para a área da cultura.

As experiências, já realizadas, de construção de sistemas de informação, com adesão e preenchimento voluntário, mostram que os municípios não se apercebem - ao menos, na sua grande maioria - da importância da sistematização dessas informações. Além disso, diante da ausência de planejamento sobre a divulgação de seu patrimônio e equipamentos culturais, os sistemas informatizados de cultura significam, em muitos casos, uma vitrine para a divulgação, em vez de um sistema de apoio à decisão. Em um esforço para buscar métodos mais adequados à compreensão dessa realidade, Os autores desenvolvem, atualmente, experimentação metodológica, com auxílio da cartografia social e cultural, no universo da rede dos pontos de cultura da região Sul. $^{10}$

Sobre os sistemas instalados nos espaços locais, espalhados de norte a sul do país, serão socialmente construídos os territórios locais, frutos da participação qualificada na disputa por posições no campo da cultura de agentes sociais fortalecidos. Mas a que fortalecimento nos referimos? Mesmo com ressalvas, que neste texto não poderemos discutir, defendemos que a eficiência - a qual, numa definição cara ao gerencialismo resulta da "relação técnica entre entradas e saídas" - não pode ser anteposta à construção do cidadão que, dono de sua consciência, participe da construção de um sistema que contribua na reforma do Estado brasileiro para uma gestão democrática e uma finalidade substantiva.

\footnotetext{
${ }^{10}$ Trata-se do projeto O Sistema Nacional de Cultura e as Dinâmicas dos Territórios: uma Cartografia do Campo Cultural no Rio Grande do Sul, aprovado no âmbito do Edital MCT/CNPq nํ02/2009 - Ciências Humanas, Sociais e Sociais Aplicadas.
} 


\section{Referências}

A ERA Vargas $-1^{\circ}$ tempo: dos anos 20 a 1945 . Rio de Janeiro: CPDOC, 1997.

BOURDIEU, Pierre. Razões práticas: sobre a teoria da ação, Campinas: Papirus, 1996.

BOURDIEU, Pierre, O poder simbólico, Rio de Janeiro: Bertrand Brasil, 2005.

BRANT, Leonardo. Mercado cultural: panorama crítico e guia prático para gestão e captação de recursos. 4.ed. São Paulo: Escrituras Editora/Instituto Pensarte, 2004. (Coleção Visões da cultura).

BRASIL. Ministério da Cultura (MinC)/Secretaria de Articulação Institucional (SAI). Proposta de estruturação, institucionalização e implementação do Sistema Nacional de Cultura. Disponível em: <http://www.cultura.gov.br/site/200g/11/03/semana-da-cultura2/>. Acesso em: nov. 2009, 2009a.

BRASIL. Ministério da Cultura (MinC)/Secretaria de Articulação Institucional (SAl). Ofício-Circular nº 019/2009/SAl-MinC. Disponível em: <http://blogs.cultura.gov.br/cnc/2009/11/19/oficio-circular-n\%C2\%BA-0192009sai-minc/>. Acesso em: nov. 2009, $2009 \mathrm{~b}$.

CARVALHO, Cristina Amélia. Configuração do campo da cultura no contexto da incorporação da lógica mercantil e os novos atores organizacionais. Projeto CNPq, 2003.

COLIGAÇÃO LULA PRESIDENTE. A imaginação a serviço do Brasil: programa de políticas públicas de cultura. São Paulo, 2002. 28p. Disponível em: <http://www.lula.org.br> Acesso em: 15 jul. 2005.

CURY, Cláudia Engler. Políticas culturais no Brasil: subsídios para lembrar construções de brasilidade. 2002. Tese (doutorado) Faculdade de Educação, Universidade Estadual de Campinas, São Paulo, 2002.

FREIRE, Paulo. Pedagogia do oprimido. 17.ed. Rio de Janeiro: Paz e Terra, 1987.

Política e educação: ensaios. 5.ed. São Paulo: Cortez, 2001.

GUERREIRO RAMOS, Alberto. A redução sociológica: introdução ao estudo da razão sociológica. 2.ed. Rio de Janeiro: Tempo Brasileiro, 1965 .

HOLANDA, Luciana Araújo de. Pela construção de outro organizar: coprodução de conhecimento a partir da experiência de sujeitos da cultura popular. Projeto de Tese de Doutorado apresentado ao Programa de Pós-graduação em Administração da Universidade Federal de Pernambuco, 2009.

IBGE - Instituto Brasileiro de Geografia e Estatística. Perfil dos municípios brasileiros: cultura 2006. Rio de Janeiro, 2007.

MATUS, Carlos. Adeus senhor presidente: governantes e governados. São Paulo: Fundap, 1996a.

Estratégias políticas: chimpanzé, Maquiavel e Gandhi. São Paulo: Fundap, 1996b.

Política, planejamento \& governo. $3^{\mathrm{a}}$ ed. Brasília: IPEA, 1997.

MÉSZÁROS, István. O poder da ideologia. São Paulo: Editorial Boitempo, 2004.

MISOCZKY, Maria Ceci Araújo. O campo da atenção à saúde após a Constituição de 1988: uma narrativa de sua produção social, Porto Alegre: Dacasa Editora/PDG Saúde, 2002.

MOISÉS, José Álvaro. Os efeitos das leis de incentivo In: WEFFORT, Francisco; SOUZA, Márcio (Org.). Um olhar sobre a cultura brasileira. Rio de Janeiro: Associação de Amigos da Funarte, 1998.

SANTOS, Boaventura de Sousa. Introdução a uma ciência pós-moderna. Rio de Janeiro: Graal, 1989.

THIRY-CHERQUES, Hermano R. Pierre Bourdieu: a teoria na prática. Revista de Administração Pública, Rio de Janeiro, v.40, n.1, p.27-56, jan./fev. 2006

VILAS-BOAS, Rosa. Gestão cultural. In: RUBIM, Linda (Org.). Organização e produção da cultura. Salvador: Edufba; Facom/Cult, 2005. 